\title{
A (Liberal) Sheep in (Marxist) Wolf's Clothing? Reassessing Antonio Gramsci's Conceptualisation of Hegemony
}

\author{
¿Una Oveja (Liberal) con Piel de Lobo (Marxista)? \\ Reexaminando la Conceptualización de la Hegemonía de Antonio \\ Gramsci
}

\begin{abstract}
Antonio Gramsci's greatest contribution to Western political thought, arguably, is his conceptualisation of hegemony. Sadly, a widespread tendency to misinterpret the term as being analogous to 'leadership based upon consent', has reduced power to ideological control: an essentially liberal perspective. This paper aims to rectify this error, carrying out a more comprehensive analysis of Gramsci's conceptualisation of hegemony as expounded in his Prison Notebooks, set against the backdrop of his own political/intellectual evolution. Hegemony, as a result, is shown to be compatible with Marxist theories of power, i.e. necessarily materially-rooted and underpinned by coercion.
\end{abstract}

Keywords: Gramsci, hegemony, morphogenetic approach, "integral State", philosophy of praxis, materialism.

JONATHAN PASS*

\begin{abstract}
Resumen: La contribución más importante de Antonio Gramsci al ámbito del pensamiento político, tal vez, es su conceptualización de la hegemonía. Por desgracia, hay una tendencia bien extendida a interpretar el término como análogo al "liderazgo basado en el consenso", y así reducir el concepto de poder al control ideológico: una perspectiva esencialmente liberal. El objetivo de este artículo es rectificar dicho error, llevando a cabo un análisis más completo de la conceptualización de la hegemonía tal y como se expuso en sus Cuadernos de Cárcel, teniendo como telón de fondo la evolución política e intelectual de su autor. Como consecuencia, la hegemonía se muestra compatible con las teorías marxistas de poder, es decir, necesariamente enraizada en el materialismo y respaldada por la coerción.

Palabras claves: Gramsci, hegemonía, enfoque morfogenético, "Estado integral", filosofía de la praxis, materialismo.
\end{abstract}

\section{Introduction}

Written during his eight-year incarceration, the Prison Notebooks $(P N)$ would be Antonio Gramsci's opus magnus: a touchstone of Western Marxism. Unfortunately, analysing the $P N$ is no easy task. Writing style, aside - no doubt conditioned by the context of its production ${ }^{1}$

Recibido: 27/04/2017. Aceptado: 29/01/2018.

* Profesor Asociado de Derecho Internacional Público y Relaciones Internacionales de la Universidad Pablo de Olavide. Sus principales líneas de investigación son la perspectiva gramsciana/neogramsciana de las relaciones internacionales, la hegemonía americana, el significado del auge de China para el orden mundial. Contacto: jonapass@upo.es

1 Apart from suffering grave health problems, Gramsci had to work with basic writing materials, limited books, bad lighting and heavy prison censorship, the latter reflected in the use of spaces, allusions, hidden meanings and modified terminology. 
- the greatest challenge posed for the reader is how to get a 'global vision' of such a large collection of fragmentary and incomplete essays. We are, after all, in the presence of an unpublished work, whose author was denied the basic privilege of being able to re-edit and systematise his notes into a single coherent corpus. Little wonder, therefore, that various, often contradictory, interpretations of $P N$ are possible.

Academic scholars and political activists alike have drawn inspiration from what perhaps is Gramsci's greatest contribution to Western political philosophy: the conceptualisation of hegemony. Sadly, a tendency to interpret hegemony as being solely based on consensual and ideological/discursive aspects have led to Gramsci being wrongly depicted as an agencyfocused idealist, and adopted by both Eurocommunists and post-Marxist radical-democrats such as Ernesto Laclau and Chantal Mouffe ${ }^{2}$ (who in turn constitute a major source of ideological inspiration for new left-wing parties such as Podemos and La France Insoumise). Such a perspective, however, is clearly at odds with the political life of a revolutionary activist who died an unrepentant communist in a fascist jail.

In order to rectify this oversight, it is necessary to carry out an 'authentic' reading of Gramsci. Given the aforementioned constraints, the best way this can be done is by following his own methodological advice: "If one wishes to study the birth of a conception of the world which has never been systematically expounded by its founder...[i]t is necessary, first of all to reconstruct the process of intellectual development of the thinker in question in order to identify those elements which were to become stable and permanent". Ultimately, one must "[s] earch for the Leitmotiv, for the rhythm of the thought as it develops"3.

The following section aims to do just that, contextualising the Sardinian's prison production within the trajectory of his prior intellectual and political life. Gramsci, after all, dedicated much of the $P N$, to trying to extract conclusions from his political participation in numerous social struggles between 1913 and 1926.

\section{Pre-Prison Political Evolution}

Antonio Gramsci's earliest intellectual influences were undoubtedly of a liberal orientation, noticeably, fellow Italian political and cultural figures such as Benedetto Croce, Giovanni Gentile and the playwright Luigi Pirandello. Though aware of socialist thinkers such as Antonio Labriola, when it came to analysing Italian economic development - predominantly the structural exploitative relationship between the dominant industrial North and the subservient agrarian South (including his native Sardinia) - the young Gramsci tended to do so from an idealist-nationalist perspective.

It was only when he went to Turin, the industrial centre of Italy, that Gramsci's political tendencies shifted leftward, becoming aware that behind the simplistic North-South dichotomy lay a more complex inter-regional dialectic based upon social class, with the Turin urban proletariat (many connected the emerging automotive sector industry around FIAT ) just as exploited as the Sardinian peasantry. In 1913 Gramsci first witnessed the importance

2 Laclau. E. \& Mouffe, C. (2001), Hegemony and Socialist Strategy: Towards a Radical Democratic Politics, $2^{\text {nd }}$ Edition, London, Verso.

3 Gramsci, A. (1971), Selections from the Prison Notebooks of Antonio Gramsci, ed. and trans. by Q. Hoare \& G. Nowell Smith, London, Lawrence \& Wishart, pp.382-83. 
of political organisation, as factions of the working class began to set up militant work councils and trade unions. That same year he joined the Partito Socialista Italiano (PSI), and stepping up his left-wing grass-roots political activism.

Digressing somewhat from the then-Marxist orthodoxy, however, Gramsci insisted that any political programme for progressive social change had to incorporate cultural concerns, writing regular political columns and theatre reviews for the PSI weekly Il Grido del Popolo and the Turin edition of Avanti! (becoming co-editor in 1916), amongst other initiatives ${ }^{4}$ all aimed at directing nationalist sentiment towards revolutionary activity amidst opposition to Italy's entrance into the First World War.

Gramsci's political education was also heavily conditioned by intra-Left debates raging within the ranks of the Social Democratic Party of Germany (SPD), throughout the Second International and beyond, with revisionists (e.g. Eduard Bernstein and Karl Kautsky) clashing with adventurists (e.g. Rosa Luxembourg and Karl Liebknecht). Gramsci and fellow PSI member were firmly in the latter camp. Swept up in the post-Bolshevik Revolution enthusiasm (and the post-war economic down-turn), they would spend the next three years supporting proletarian insurrections and political mobilisation throughout Italy, acting on the Third International's insistence that workers use "all available means" to overthrow the international bourgeoisie.

In his call to action he published an article entitled "The Revolution Against 'Capital", in Il Grido del Popolo, on $5^{\text {th }}$ January 1918, in which he countered Menshevik claims that the Bolsheviks had ignored the pre-ordained 'historical laws' of capitalist development. The revolutionaries, he maintained, "have not used the works of the Master to compile a rigid doctrine of dogmatic utterances", but rather "live Marxism thought - that thought which is eternal, which represents the continuation of German and Italian idealism, and which in the case of Marx was contaminated by positivist and naturalist encrustations". They had recognised the implicitly political nature of the economy, "men in relation to another", rather than just "raw economic facts". 5

Such quotes, taken out of context, could lead to the erroneous conclusion that Gramsci was a closet liberal. Yet even during this so-called "voluntarist" period he made it clear that "if the Bolsheviks reject some of the statements of Capital, they do not reject its invigorating, immanent thought" ${ }^{6}$ - remaining true to the spirit of Marx's thinking in Theses on Feuerbach, which urged political action over intellectual musings. ${ }^{7}$ The Russian Revolution, if anything, had convinced him of the validity of Marxist thought, not in an abstract, ahistoric, or determinist sense, but in supplying a set of powerful concepts, categories and tools to explain an ever-changing social world.

4 In 1917, for example, he helped to set up a short-lived Il Club di Vita Morale (the Moral Life Club) -dedicated to the political education, and sponsorship of proletarian culture amongst young socialists - and founded the newspaper La Cittá Futura (The Future City) - submitting articles on the nature of state formation in Italy, the reorganisation of society and capitalism through periods of crisis, production techniques, the Russian Revolution, and how to build socialism in Italy.

5 Gramsci, A. (1977), "The Revolution Against 'Capital”,, Selections from Political Writings, 1910-1920, London, Lawrence \& Wishart, pp.34-35.

6 Ibid

7 Marx, K. \& Engels, F. (2002), “Theses on Feuerbach”, Selected Works, Vol.1. http://www.marxists.org/archive/ marx/works/1845/theses/theses.htm 
This amounted to what Gramsci would later refer to as "philosophy of praxis", which in the hands of Marx and Lenin ("the greatest modern theoretician"), signified the union of theory (thought) and practise (deed), or "history in action", manifested by the mobilisation and consolidation of the exploited classes into a 'collective will', en route to a 'revolution from below'. ${ }^{9}$ This was indeed the political project that obsessed the Sardinian during Italy's bienno rosso (the "two red years"): the period of profound rural and industrial unrest from 1919-20.

In order to raise critical and active consciousness, and therein fuse theory and practise, Gramsci co-founded L'Ordine Nuovo: Rassegna Settimanale di Cultura Socialista in April 1919, along with Angelo Tasca, Palmiro Togliatti and Umberto Terracini. This highly influential revolutionary journal provided pivotal ideological support for the proletarian struggle in Turin - the most advanced at the time in Italy - although one which he himself would later criticise for its naivete and programmatic vagueness. ${ }^{10}$

But even so Gramsci eschewed revisionism, using the journal to attack traditional trade unions, ${ }^{11}$ lamenting their: a) highly bureaucratic and undemocratic nature (which alienated and depoliticised workers); and b) intrinsically capitalist nature (i.e. junior partners dedicated to the regulation of capitalist-labour relations within the capitalist system). Since these could never be "the instrument for radical renovation of society" 12 , Gramsci proposed Factory Councils - a sort of Italian version of Russia's soviets - based around new autonomous shop committees, as part of a broader programme to raise working-class consciousness and rejuvenate the Left.

The final stage of Gramsci's more 'opportunist' political activism ran roughly from September 1920 to May 1921, during which he came to appreciate a) the structural power of capitalist hegemony (including the capitalist state); and b) the organisational weakness of a divided Left, as exposed with the failure of the April 1919 'general strike' and the collapse of the Turin Factory Council experiment, Accordingly, Gramsci and fellow L'Ordine Nuovo members accepted the need to found a "cohesive and highly disciplined Communist Party with factory, trade union and cooperative cells, that can coordinate and centralise in its central executive committee the whole of the revolutionary action"13, an initiative officially endorsed by Lenin ${ }^{14}$. In October 1920, the Partito Comunista Italiano (PCI) manifesto first appeared, co-written by Gramsci and Antonio Bordiga, with the party holding its First National Conference in January 1921.

The international Left was also undergoing a tactical revaluation. Three months after the German Communist Party (KPD) had its attempted seizure of power ("March Action")

8 Gramsci (1971), p.56f.

9 Gramsci (1977), pp. 65-68

10 He later justified the initiative as arising out of the need to do something: "we wanted to act, to act, to act". Gramsci (1971), xxxvii

11 Such as the national trade union federation, the Confederazione Generale del Lavoro (CGL), and the metalworkers' union, the Federazione Impiegati Operai Metallurgica (FIOM)

12 Gramsci (1977), p.99. Gramsci, A. (1978), Selections from Political Writings, 1921-1926, ed. and trans. Q. Hoare. London, Lawrence \& Wishart, p.76

13 See Gramsci (1977), pp190-95.

14 Lenin, V. (1982), Collected Works, Volume 31, p251, Moscow, Available On-line at http://www.marxists.org/ archive/lenin/works/1920/jul/x03.htm. 
unmercifully crushed by state coercive forces, Lenin announced the new official strategic line at the Third Congress of the Communist International (June-July, 1921). The installation of a socialist state in the West would require more than such foolhardy adventurism. Under the slogan "to the masses" communist parties everywhere were encouraged to engage in coalition-building with other rival left-leaning parties, trade unions and working-class associations, in order to engender a mass movement: a "United Front" 'from below', in a common struggle against capital. Gramsci later referred to this shift in official Comintern strategy between March 1917 and March 1921, as representing a move from a "war of manoeuvre" to a "war of position", ${ }_{15}$ the latter of which he considered essentially an expansion of Marx's earlier calls for a "Permanent Revolution"16.

The United Front policy generated much debate within the PCI: originally welcomed by both Gramsci and Tasca as a way to combat the rising popularity of the Italian National Fascist Party ${ }^{17}$, but fiercely opposed by Bordiga, who jealously guarded the supremacy and 'purism' of the PCI. Despite sympathy for Tasca and his cultural concerns ${ }^{18}$, Gramsci initially stood by Bordiga, repudiating Trotsky's demands to merge the PCI with the PSI, claiming the latter was more a peasant-based petit bourgeois party than proletarian party.

Gramsci's final conversion to the United Front cause - and abandonment of Bordiga's 'national exceptionalist' position - came in the spring of 1923, as a result of: a) a year of socialization in Moscow as the PCI's delegate to the Comintern; b) increased violence and subsequent seizure of power by the Italian Fascist Party in October 192219; and c) the divided and disaffected state of the Italian Left ${ }^{20}$. His last two years as a free man $^{21}$ were spent working tirelessly to build a United Front with other left-wing/progressive factions, ${ }^{22}$ organising labour into factory groups, worker and peasant committees, drawing on many of the ideas developed in the L'Ordine Nuovo (which was actually revived in the spring of 1924) $)^{23}$, and helping boost PCI membership considerably ${ }^{24}$.

15 Gramsci (1971), p.120

16 Gramsci (1971), pp.242-43

17 Gramsci was one of the first to recognise the unique nature of fascism and the huge dangers it posed for freedom, democracy and the working classes in general. For Bordiga, on the other hand, fascism, liberalism and social democracy were basically all the same.

18 To that end, and inspired by the vanguard futuristic Bolshevik art movement, Gramsci set up in 1921 the Institute of Proletarian Culture, the Italian section of the Muscovite Prolekult Institute

19 Violent state repression of opposition groups took place throughout 1922-23 as political parties, organisations, unions and the free press were crushed and leaders arrested, including Bordiga.

20 The economic crisis of 1921-22 saw working-class support for the Left plummet, reflected in a massive decline in the membership of the PSI, PCI and CGL and a proportional rise in support for fascism. See Cammett (1967), p153.

21 He returning from exile in Vienna in 1924 to occupy his position as PCI deputy for Veneto in the Chamber of Deputies, under the protection of parliamentary immunity, supposedly.

22 While always retaining his staunch opposition to pluralism, Gramsci regularly participated in parliamentary opposition group meetings, urging other parties to join the PCI in an anti-fascist bloc (which they refused).

23 Gramsci launched a new daily newspaper in February 1924, L'Unità, with the specific aim of incorporating the Southern peasantry into a class alliance with the Northern working-class movement; a reoccurring political theme throughout his life (see the "Southern Question" below).

24 Cammett (1967), p.169 
Eventually, heightened fascist persecution forced the PCI to go underground, but not before it presented its final important strategy statement at their Third Congress in Lyons (France), in January 1926, later known as the "Lyons Theses". ${ }^{25}$ In his intervention entitled "The Italian Situation and Tasks of the PCI" (co-credited to Togliatti), Gramsci reviewed recent historical developments before setting out his views on the construction, organisation, functioning and ideological basis of the PCI, introducing the concept of hegemony for the very first time, reiterating on one hand, the critical leadership role of the PCI in organising and unifying the proletarian vanguard, working class and peasantry while, on the other hand, insisting on the imperatives of establishing a broad United Front with other anti-Fascist and anti-imperial forces.

Leaving no room for liberal pluralist interpretation, the Sardinian emphasized that such coalition partners had to share the revolutionary objectives of the PCI and support the establishment of a new socialist state, since this was the only feasible way the working class could achieve emancipation given exploitative and highly unjust nature of the capitalist system.

\section{Misreading Gramsci}

Once imprisoned ${ }^{26}$, and deprived the right of direct political participation, Gramsci had little choice but to channel his energies into intellectual theorising, granted permission to begin writing in February 1929. His intention, as he explained to his sister-in-law Tatiana, was to find something to occupy his time and "give a focus to (his) inner life" which he hoped nevertheless would have value "forever" 27.

Throughout his confinement, Gramsci would reflect on the lessons learnt from over a decade of political activism, and the obstacles standing in the way of achieving a communist society. In doing so, he would revise somewhat his strategic thinking, tempering his earlier "voluntarist" position with a better understanding of the structural nature of power, and how it shaped political mobilisation and delimited the possibilities of class formation.

Gramsci concluded that the single greatest obstacle to working class emancipation was the strength of the modern capitalist state. The dynamics of state formation (set within the wider international systems), occupied pride of place in his prison writings. The first line of his "Notes on Italy History", for example, begins: "[t]he historical unity of the ruling classes is realised in the state, and their history is essentially the history of states and of groups of states". Sadly, he lamented, "[t]he subaltern classes, by definition, are not unified and cannot unite until they are able to become a "state"". ${ }^{28}$

25 Gramsci (1978), pp.464-512. The central debates arising out of this Congress regarding hegemony, class, power structures, regionalism and uneven development in Italy would form the basis of Gramsci's final (though unfinished) essay as a free man in autumn 1926, Some Aspects of the Southern Question, which would constitute the first piece in the $P N$.

26 He was arrested in Rome on the $8^{\text {th }}$ November 1926 in accordance with a series of "Exceptional Laws", and sentenced to 20 years, 4 months and 5 days, on the $4^{\text {th }}$ June $4,1928$.

27 Gramsci (1971), p.xcii

28 Gramsci (1971), p.52 
But what was the source of the modern capitalist state's on-going stability and resilience? Although Marx never really developed a comprehensive theory of the modern capitalist state what he did say was of paramount importance for Gramsci, above all with regards two fictional separations within capitalism:

1) between economic \& political structures ${ }^{29}$

2) between the State $\&$ civil society ${ }^{30}$

Since the 'bourgeois democratic republic' was essentially capitalist in nature, Gramsci always ridiculed revisionist arguments that socialism could be achieved via the bourgeois parliamentary system. But while the capitalist state's defence of private property and ongoing capital accumulation served the interests of the bourgeoisie, the question still remained as to why the working classes would consistently support a political system (sometimes in its fascist form), which so clearly clashed with their objective class interests.

It was in response to this key question that Gramsci began to elaborate his own, extremely novel, conceptualisation of hegemony. First used in Ancient Greece, though entering into modern popular discourse in $19^{\text {th }}$ Century Russia, it was Lenin, ${ }^{31}$ according to Gramsci, who "gave new weight...to the front of cultural struggle, and constructed the doctrine of hegemony as a complement to the theory of the State-as-force", ${ }^{32}$ influencing debates throughout leftist circles in the early $20^{\text {th }}$ Century, gaining special prominence during the first four World Congresses of the Third International.

As noted above, it was as part of the PCI's drive for a Leninist-inspired United Front in Italy that Gramsci's first began to elaborate a theory on the dynamics of hegemony ("Lyons Theses"). Years of political activism had made it crystal clear that building working-class hegemony in an advance capitalist country was no easy task, reflected in the Comintern's

29 Capitalism, unlike prior modes of production, Marx held, involved the extraction (by the capitalist) of surplus value generated (by labour) in an apparent non-political manner, appearing merely an exchange relationship between 'consenting adults'. Liberals portrayed the market as an opportunity, but the proletariat, stripped of its means of subsistence, had little choice but to sell its labour to capitalist (compulsion). The appropriation of surplus value under capitalism, thus, no longer needed to resort to overt and excessive 'extra-economic' compulsion (e.g. violence), the 'logic of the market' would largely suffice. This 'market', however, remained highly political, despite appearances. See Marx, K. (2008), Capital: Critique of Political Economy, "Book 1: The Process of Production of Capital, Online version, http://www.marxistsfr.org/archive/marx/works/download/ Marx_Capital_Vol_1

30 Liberal democracy, Marx observed, ideologically legitimised capitalism by isolating (public) political society (state sovereignty) from (private) civil society (the market/individual rights). In the State, citizens were recognised as judicially free and equal political persons, while in civil society, on the other hand, they clearly remained unequal economic citizens. By prioritising abstract citizenship above class identity, the working class was de-politicised. Marx, K. (1999), Critique of Hegel's Philosophy of Right, Online version, https://www. marxists.org/archive/marx/works/1859/critique-pol-economy/

31 Writing in What is to be Done? (1902) and Two Tactics of Social Democracy (1905), Lenin urged the proletariat to exercise hegemony - implying the leadership with consent - over allied opposition classes such as the peasantry, to form a broad-based United Front in the bid to overthrow the Tsarist regime. Lenin (1982), Vol.17, pp. 232-33, see also pp.78-79.

32 Gramsci (1971), p.56f. It is worth reiterating here, for future reference, that Gramsci considered hegemony a "complement to", not a "replacement of", the "state-as-force". 
adoption of the "war of position" in 1922. Strategically, therefore, any talk of proletarian emancipation required the prior examination of the underlying dynamics, structural stability and self-reproduction tendencies of bourgeois hegemony. This divergence in focus meant Gramsci's conceptualisation of hegemony was far more complex than Lenin's, and drew upon sources from outside the classic Marxist canon.

Considering hegemony was ultimately about the exercising and maintenance of power, the prisoner opted to re-read "the most classic master of the art of politics for the Italian ruling classes", renaissance political philosopher, Niccolò Machiavelli. ${ }^{33}$ Studying The Prince, Gramsci became fascinated by Machiavelli's observations regarding the founding of a new state; seeing uncanny parallels between their apparently very different research agendas. But leading his social construction project would not be an elitist cabal (as in Machiavelli's Prince), but a vanguard party supported by the mass public consistent with the Leninist United Front line: a Modern Prince. ${ }^{34}$

What most grabbed Gramsci's attention was Machiavelli's conceptualisation of power. Famously drawing on an analogy of the centaur - the mythical Greek "half beast and half man" character - the exercising of power, he asserted, relied on a combination of consent and coercion..$^{35}$

For a state to be successful, Machiavelli declared, it was fundamental that the ruler not only maintained the prestige the said office demanded, but that he worked to gain the active consent of his subjects, for "when a prince has the goodwill of the people he must not worry about conspiracies". ${ }^{36}$ Where compliance of the dominated could not be guaranteed solely by consent, however, coercion was recommended (along with fear, deception, fraud and bribery). Machiavelli only considered the rulings class truly hegemonic, however, to the extent to which they were able to control subordinate groups via the consensual aspect of power. ${ }^{37}$

On first reading, therefore, it appeared that coercion ("domination") was generally reserved for enemy classes while consent/hegemony ("intellectual and moral leadership") was favoured for allies ${ }^{38}$. Such a broad distinction informed Gramsci's state-formation comparison, contrasting late $18^{\text {th }}$ Century France, led by a hegemonic "Jacobin" force, with mid-19 Century Italy (Il Risorgimento), ${ }^{39}$ exemplifying "domination without that of 'leadership'; dictatorship without hegemony" 40 . It is this particular reading of hegemony which is the source of Gramsci's categorisation as an idealist.

More than four decades ago, Perry Anderson wrote a still highly-influential article ${ }^{41}$ (at least in the Anglo-Saxon world), denouncing what he considered as the serious theoretical

33 Gramsci (1971), p.64

34 Understood as the "proclaimer and organiser" of this working class "intellectual and moral reform" centred on a new revolutionary party but evolving via "a dialectic between the intellectuals and the masses". Gramsci (1971), pp.132-33

35 Machiavelli, N. (1981), The Prince, London, Penguin Classics, Section XVIII, p.99

36 Machiavelli (1981), Section XIX, p.105

37 Machiavelli (1981), Sections XVII \& XVIII, pp.95-102

38 Gramsci (1971), p.57

39 Gramsci (1971), p.131, p.109, p.100

40 Gramsci, A (1995), Further Selections from the Prison Notebooks, ed. and trans. D. Boothman. London, Lawrence \& Wishart, p.350

41 Anderson, P. (1976), New Left Review I/100- "The Antinomies of Antonio Gramsci”, November-December 
inconsistencies of the $P N$, not least with regards hegemony, which largely derived from the prisoner simultaneously holding three contradictory conceptualisations of the modern capitalist state ${ }^{42}$.

Nevertheless, Anderson argued, the predominant model in the $P N$, influenced by Machiavelli and Croce, was one which established a formal separation ("a proper relationship") between the civil society (the "ensemble of organisms" commonly termed "private") and the State ("political society")43, and that "when the State trembled a sturdy structure of civil society was at once revealed" 44 . The State, in other words, represented merely "an outer ditch" behind which "a powerful system of fortresses and earthworks," or "trenches" of civil society institutions and associations which would repel revolutionary action. ${ }^{45}$

This perspective, Anderson maintained, was compatible with the Leninist "war of position" strategy for seizing power in an advanced capitalist state but, by splitting the political spheres (between "political sphere" and "civil society") Gramsci was guilty of philosophical dualism, reducing the social world to a simple binary opposition classification, thus ${ }^{46}$ :

$\begin{array}{lcc}\text { State } & / & \text { civil society } \\ \text { domination } & / & \text { hegemony } \\ \text { coercion } & / & \text { consensus* } \\ \text { war of movement } & / & \text { war of position } \\ \text { * incorporating "intellectual \& moral leadership" }\end{array}$

Such a categorisation had major strategic corollaries. Crucially, by classifying "civil society" (governed by consensus) as separate from, but dominant over, "political society" (underpinned by coercion), it gave the impression that the ruling class' hegemony was purely cultural: based on their ideological subordination of the working class within civil society (e.g. via the media, the non-state groups and associations, organised religion, the education system etc.). This had important tactical implications: suggesting that once this 'cultural domination' (intellectual and moral leadership) was overcome (via a "war of position") a socialist system could be established peacefully, within the framework of liberal parliamentary democracy, without the actual need for seizure of the State ("war of movement").

This reading assumed an ideologically-neutral State, unaffected by class power: a liberal or revisionist perspective, which Anderson admitted, was probably not Gramsci's intention, but which evidenced his Crocean heritage ${ }^{47}$ Yet, it was exactly this conceptualisation of hegemony as 'cultural domination' (intellectual and moral leadership), devoid of coercion

42 Anderson (1976), pp.12-14. Anderson claims Gramsci offers 3 very different conceptualizations of the relationship between the civil society and the state: i) civil society is preponderant over the state; ii) civil society is in balance with the state; iii) the state includes both political society and civil society.

43 Gramsci (1971), p.12

44 Gramsci (1971), p.238

45 Gramsci (1971), p.243

46 Anderson (1976), pp.21-26

47 Anderson (1976), pp.27-29 
or reference to social relations of production, which was adopted by Eurocommunists and radical-democrats such as Laclau and Mouffe.

Anderson's dualist reading of Gramsci (including his conceptualisation of hegemony), however, is fundamentally flawed. In order to lay to rest this liberal misinterpretation of Gramsci it is vital first to clarify his view on the relationship between structure and agency.

\section{Structure \& Agency}

Along with the aforementioned "Theses on Feuerbach", Marx's "Preface" to the Critique of Political Economy 1859 was the very first work the imprisoned Gramsci translated, and the key theoretical reference point for the $P N$, considering it "the most important authentic source for the reconstruction of the philosophy of praxis" 48 , explaining:

The question of the "objectivity" of knowledge according to the philosophy of praxis can be treated by starting from the proposition contained in the Preface to $A$ Contribution to the Critique of Political Economy that "men become conscious (of the conflict between the material forces of production) on the "ideological level" of "juridical, political, religious, artistic and philosophical forms" 49.

Rebutting liberal claims, Gramsci remained a life-long historical materialist, ridiculing Croce's "speculative philosophy" and overly idealist "ethico-political" account of history.50 Indeed, various sections of the $P N$ are dedicated to the dynamics of the political economy, whether it be at the national or global level (e.g. "Americanism and Fordism" ${ }_{51}$ ). David Ricardo was praised for introducing "new methodological canons...developing the science of economics", notably the "discovery of the formal logical principle of the 'law of tendency" which leads to the scientific definition of the fundamental economic concepts of homo oeconomicus and of the "determined market",; even declaring, "the philosophy of praxis equals Hegel plus David Ricardo". 52

Gramsci always made it very clear that the relationship between base and superstructure was dialectal, albeit materially-rooted, as shown in his definition of a "determined market": a "determined relation of social forces in a determined structure of the apparatus of production, this relationship being guaranteed (that is, rendered permanent) by a determined political, moral and juridical superstructure" 53 . In stressing the dialectic Gramsci was distancing himself from the type of vulgar "metaphysical materialism" peddled by Bukharin, whose structuralist ahistorical approach effectively eliminated agency from history.

Economic concepts and principles had to be viewed as "laws of tendency" (i.e. Marx's tendency for the profit rate to fall), only possessing validity within certain "determined markets", and always subject to counteracting propensities. Shifts in the forces of production

48 Gramsci (1971); p.460

49 Gramsci (1971), pp.371-72; Gramsci (1995), pp.343-80.

50 Ibid

51 Gramsci (1971), pp.277-318

52 Gramsci (1971), pp.400-01

53 Gramsci (1971), p.410 
did affect the relations of production, but this did not automatically manifest itself at the superstructural level in a mechanical way. Economic crises for example, might "create a terrain more favourable to the dissemination of certain modes of thought, and certain ways of posing and resolving questions" but it did not follow, as Bukharin claimed, that "immediate economic crises of themselves produce fundamental historic events" (i.e. a political crisis).$^{54}$

Croce, of course, was correct, ideas were important. Gramsci cited Marx's "Preface" that "it is on the level of ideologies that men become conscious of conflicts in the world of the economy" 55 . His own political activism in the 1920s had taught him that all praxis was driven and legitimised by inter-subjective theories of the world, and that ideas "are anything but arbitrary; they are real historical facts which must be combated and their nature as instruments of domination exposed...precisely for reasons of political struggle" 56 .

Indeed, Gramsci dedicated large tracts of the $P N$ to analysing the key 'institution' responsible for the formulation, diffusion and legitimisation of class projects in society - intellectuals ${ }^{57}$ - considering it absolutely imperative that the revolutionary party (the Modern Prince) nurture "its own organic intellectuals" in order to help challenge elite-sponsored "common sense" and replace it with true "good sense". ${ }^{58}$ Ideas, in short, were fundamental, but contrary to Anderson's liberal accusation, Gramsci was adamant that for them to have any genuine political relevance they had to have their basis in objective reality ("ideologies would be individual fancies without the material forces"59).

To summarise, rather than reifying either structure (Bukharin) or agency (Croce), therefore, Gramsci offered his own dialectical materialist philosophy of praxis, which he defined as being concerned with analysing "how the historical movement is born out of the structure" in order to reveal just how "the formation of active political groups" takes place and whether said groups are capable of engineering dramatic societal change and establish their hegemony ${ }^{60}$. Gramsci would conceptualise this contingent 'dialectical unity' between socio-economic relations on one hand (base), and political, ethical and cultural practises/ issues (superstructure) on the other, as constituting an historical bloc. ${ }^{61}$

From the above, and throughout the $P N$, it becomes evident that Gramsci's ontological and epistemological positions (i.e. ontological realism and epistemological relativism) were congruent with what Roy Bhaskar would later denominate a critical realist philosophy of

\footnotetext{
54 Gramsci (1971), p.184, p.410, p.401, pp.425-72; Gramsci (1995), pp. 189-90.

55 Gramsci (1971), p.162

56 Gramsci (1995), p.395

57 See Gramsci (1971), pp. 5-23

58 "Common sense" was "a product of history", defined as "the traditional popular conception of the world", and comprising of "beliefs, superstitions, opinions, ways of seeing and acting" expressed in conservative popular culture (e.g. customs, religious rituals etc.). "Good sense", on the other hand, was true political self-aware class consciousness en route to a genuine counter-hegemonic movement. See Gramsci (1971), p.19, p.134, pp.19697, pp.323-28, p.334

59 Gramsci (1971), p.377

60 Gramsci, A. (2007), Quaderni del Calcere: Quaderni di traduzioni (1929-1932), ed. G.Cospito \& G. Francioni, Rome, Istituto della Enciclopedia Italiana, Quarderni 11, p.1422

61 Gramsci (1971), p.137, p.366, p.418.
} 
science, ${ }^{62}$ with a conceptualisation of structure and agency akin to Margaret Archer's morphogenetic approach ${ }^{63}$. According to Archer there was an analytical (or methodological) temporal distinction between structure and agency: the former necessarily preceded the latter (at least in the first instance) both containing and enabling agents. Nonetheless, they were interdependent and engaged in a dialectical relationship and forming a dialectical organic unity. ${ }^{64}$ Importantly, such a conceptualisation was not limited to the base-structure metaphor, but extended to the other binary oppositions cited by Anderson (i.e. State-civil society, hegemony-domination, coercion-consensus, and war of movement-war of position).

\section{4. 'Integral State" \& Hegemony}

Addressing the State-civil society dichotomy first. In contrast to liberal theory ${ }^{65}$, Gramsci adhered to the standard Marxist line (reiterated in "Lyon Theses"), that the modern capitalist state was a vehicle of bourgeois class power and as such extended beyond the public sphere into the private sector. Nevertheless, and coinciding with Archer's approach, Gramsci saw it necessary to make an analytical distinction between these "two major superstructural 'levels'" - the State (political society) and civil society (private society) - due to the different "functions" they carried out. To the former corresponded the function of " direct domination' or command exercised through the State and "judicial' government"; to the latter the "function of 'hegemony' which the dominant group exercised throughout society" 66 .

In response to Anderson, it is vital to stress here that when Gramsci referred to the respective functions of "political society" and "civil society" he did not consider that they occupied separate political spaces; indeed, he directly accused Aristotle and Croce of committing the "theoretical error" of separating civil society from the State: a "methodological distinction", "presented as organic distinction", whereas in "effectual reality", "civil society and the state identify themselves." 67 Gramsci often chose to bracket each term within quotation marks "political society" and "civil society" to underscore the qualified nature of their separation, when in reality they were engaged in a dialectical and non-exclusionary relationship, distinguishable methodologically but not organically.

What Gramsci actually did was to enlarge the State to encompass both "political society" and "civil society": each one intricately interconnected and mutually penetrating the other,

62 See Bhaskar, R. (1975), A Realist Theory of Science, Leeds: Leeds Books; Bhaskar, R. (1979), The Possibility of Naturalism, Hemel Hempstead, Harvester Press; and Bhaskar, R. (1986), Scientific Realism and Human Emancipation, London, Verso.

63 First set out in Archer, M.S. (1990), "Human Agency and Social Structure: A Critique of Giddens" in J. Clark, C Modgil and S. Modgil (eds.), Anthony Giddens: Consensus and Controversy, Brighton, Falmer Press, pp73-84

64 Archer's morphogenetic approach adopts a diachronic and sequential mode of analysis expressed in a 3-stage morphogenetic cycle in which structural conditions pre-condition social interaction, which leads to structural elaboration (morphogenesis) or reproduction (morphostasis), which in turn preconditions future interaction, and the subsequent launching of a new morphogenetic cycle. See Archer, M. S.: (1995), Realist Social Theory: The Morphogenetic Approach, Cambridge: Cambridge University Press.

65 Gramsci referred to this as "statolatry, which reduced the State to a "night watchman" safeguarding public order, a "government by functionaries", a "perpetual entity". Gramsci (1971), pp.268-9.

66 Gramsci (1971), p.12.

67 Gramsci, A. (2007), Quarderni 13: p.1590. 
as part of an organic whole. It was this complex dialectical conceptualization of the State the "integral State" - which constitutes one of Gramsci's most sophisticated contribution to Marxist thought, and one which Anderson and other critics failed to acknowledge.

This integral State was composed of "the entire complex of practical and theoretical activities with which the ruling class not only justifies and maintains its dominance, but manages to win the active consent of those over whom it rules", referred to on separate occasions as "hegemony protected by the armour of coercion", or alternatively as "dictatorship + hegemony". Any attempt at separating social forces within "civil society" from power in "political society" was futile. It is in this context that the affirmation that "in actual reality civil society and the State are one and the same" can be better understood. ${ }^{6}$

Conceptualising the State as an integral State has another important corollary for hegemony: it becomes impossible to locate hegemony solely in just one of the "two superstructural levels". According to Peter D. Thomas, it must be conceived "as a practice 'traversing' the boundaries between them...a particular practise of consolidating social forces and condensing them into political power on a mass basis", thus "the exercise of hegemony, initially elaborated within civil society, also impacts upon... [the] "political society or State"". Indeed, it must necessarily do so, Thomas continued, "because political society itself and the power concentrated in it are integrally related to civil society and its social forces, as their mediated, 'higher' forms" 69 .

Hegemony, thus, tended to reproduce itself. Though originally "based on the decisive function exercised by the leading group in the decisive nucleus of economic activity"70, hegemony worked right across both 'superstructural levels', able to bolster certain social forces within "civil society" and their subsequent consolidation into a coherent "political force", which, in turn, would then help reinforce (often by coercion) the position of said social forces within "civil society".

The very stability of "political society" in advanced capitalist states relied on the hegemonic class generating consensus within civil society via the "hegemonic apparatus": an intricately web of opinion-forming and artistic institutions, such as media groups, publishing houses, education organisations, clubs and societies, religious groups, theatres, music halls and art galleries. ${ }^{71}$ Gramsci was quick to stress its importance: "The realisation of a hegemonic apparatus, in so far as it creates a new ideological terrain determines a reform of consciousness and methods of knowledge: it is a fact, a philosophical fact". ${ }^{72}$

Thomas defined the hegemonic apparatus as the "class-focused" complement to Gramsci's conceptualisation of the integral State such that if the latter "seeks to delineate the forms and modalities by which a given class stabilises and makes more or less enduring its institutional-political power in political society, the concept of 'hegemonic apparatus' attempts to chart the ways in which it ascends to power through the intricate network of social relationships of civil society"; in other words it constitutes "the means by which a

68 See Gramsci (1971), p.244, p.263, p.239, p.160

69 Thomas (2010), p.194

70 Gramsci (1971), p.161

71 Gramsci (1996), pp.52-53.

72 Gramsci (1971), pp.365-66 
class's forces in civil society are translated into political power". ${ }^{73}$ The social power (hegemony) in "civil society" was, therefore, of an intangible nature and took a "diffused and capillary form", mediated through various organisations ${ }^{74}$.

The expansion of the bourgeois hegemony was therefore not left to "civil society" alone but extended in to "political society". Gramsci was one of the first Marxian thinkers to stress the key ideological importance of representative parliamentary democracy in legitimising, and thereby upholding, bourgeois hegemony in the West. ${ }^{75}$ The "State" itself was transformed into an inter-subjective "educator"76, responsible for adjusting the "civil society" to the "structure" in the interests of the dominant classes, "creating new and higher types of civilisation", moulding "civilisation' and morality of vast masses to the necessities of the continuous developments of the economic apparatus of production", and all "without 'sanctions' and without compulsory 'obligations.". ${ }^{77}$

Finally, and in contrast to Anderson's simplified dualist depiction of Gramsci, it was not a question of hegemony (consensus) or domination (coercion). The use of coercion remained fundamental to exercising hegemony, and not only reserved to discipline opponents ("those groups which do not 'consent' neither actively nor passively"), but it also applied to society as whole, even for allies, especially when "spontaneous consent fades away"78. The "parliamentary regime", itself, was "characterised by the combination of force and consent...without force predominating excessively over consent", and occasional recourse to fraud and corruption. ${ }^{79}$ Furthermore, in the struggle for hegemony, Gramsci emphasized the importance of the third "moment" of his "relations of forces" analysis - "the relation of military forces" - which was "from time to time... directly decisive". ${ }^{80}$

Nor was coercion only evident in "political society". Gramsci, along with all Marxist thinkers believed that there was an inherently conflictual class relationship between the bourgeoisie within the capitalist mode of production. State action was not limited to "political sphere" but played an important role in overseeing the "dull compulsion of economic relations" 81 and guaranteeing on-going capital accumulation, either via its guardian role (protecting private property, enforcing contracts and regulating markets), or more overtly, directly intervening to restore profitability levels, nurture businesses ("manufacturing the manufacturers"), transform the existing social structure and undermining working-class political organisation. Even laissez-faire economics, he reflected, was "introduced and maintained by legislative and coercive means". 82

73 Thomas (2010), pp.224-26

74 Gramsci (1971), p.110

75 Being allowed to vote in periodic elections and having certain key civil and political rights formally recognised was often sufficient to guarantee the public's inferred support for the liberal democratic political system. After all, liberal democratic theory held that sovereignty ultimately rested in the people themselves.

76 Gramsci (2007), Quarderni 8, p.37

77 Gramsci (2007), Quarderni 13, p. 1566

78 Gramsci (2007), Quarderni 12, p1519

79 Gramsci (1971), p.80f

80 Gramsci (1971), p.183

81 Marx (1967), p.737

82 Gramsci (1995), p.261, pp.243-44, p.160; Gramsci (1971), p.160 
In short, the misrepresentation of Gramsci's ideas does him a great disservice. A deeper contextualised reading of the $P N$ has revealed the sophistication of his handling of the structure-agency question, which contrasts with the simplistic dualist philosophy (and reliance on binary opposition) traditionally held by liberals (e.g. State/civil society, domination/ hegemony, coercion/consensus, politics/economic/politics, etc.).

Once each of the above dichotomies is understood as consisting of analytically distinct, but dialectically integrated, elements within an organic whole it is far easier to understand and explain the functioning of the social world, or at least to better appreciate the utility and subtleties of Gramsci's concepts, such as integral State, historical bloc, hegemonic apparatus, organic intellectual or hegemony itself, which, as observed, necessarily encompasses both coercion (or political domination) and consensus (intellectual and moral leadership).

Decades of political activism and theoretical writings refute those claims situating Gramsci in a liberal, Eurocommunist or revisionist camp. Despite his commitment to a United Front "war of movement" strategy, he died an unrepentant communist militant, never under any illusions that the dismantling of embedded capitalist power structures would inevitably involve armed insurrection by the masses. In a conversation with fellow prison inmate, Athos Lisa, in 1933, Gramsci explained:

The violent conquest of power necessitates the creation by the party of the working class of an organisation of the military type...capable of wounding and inflicting grave blows on it at the decisive moment of struggle ${ }^{83}$.

\section{References}

Althusser, L. \& Balibar, E. (1970), Reading Capital, London, New Left Books.

Anderson, P.(1976), “The Antinomies of Antonio Gramsci”, New Left Review I/100,NovemberDecember, 1976.

Archer, M.S. (1990), "Human Agency and Social Structure: A Critique of Giddens" in J. Clark, C Modgil and S. Modgil (eds.): Anthony Giddens: Consensus and Controversy, Brighton, Falmer Press.

Archer, M. S. (1995), Realist Social Theory: The Morphogenetic Approach, Cambridge, Cambridge University Press.

Bhaskar, R. (1975), A Realist Theory of Science, Leeds, Leeds Books.

Bhaskar, R. (1979), The Possibility of Naturalism, Hemel Hempstead, Harvester Press.

Bhaskar, R. (1986), Scientific Realism and Human Emancipation, London, Verso.

Cammett, J. (1967), Antonio Gramsci and the Origins of Italian Communism, Stanford, Stanford University Press.

Clark, M. (1978), Antonio Gramsci and the Revolution that Failed, New Haven, Yale University Press.

Fiori, G. (1970), Antonio Gramsci: Life of Revolutionary, London, New Left Books.

Fernández Buey, F. (2001), Leyendo a Gramsci, Barcelona, El Viejo Topo.

83 “The Athos Lisa Report 1933”, quoted in Anderson (1976), p.72. 
Gramsci, A. (1971), Selections from the Prison Notebooks of Antonio Gramsci, ed. and trans. by Q. Hoare \& G. Nowell Smith, London, Lawrence \& Wishart.

Gramsci, A. (1975), History, Philosophy and Culture in the Young Gramsci, edited by Cavalcanti, P. \& Piccone, P. Saint Louis, Telos Press.

Gramsci, A. (1977), “The Revolution Against 'Capital”,, Selections from Political Writings, 1910-1920, London, Lawrence \& Wishart.

Gramsci, A. (1978), Selections from Political Writings, 1921-1926, ed. and trans. Q. Hoare, London, Lawrence \& Wishart.

Gramsci, A. (1994), Pre-Prison Writings, ed. R. Bellamy, trans. V. Cox, Cambridge, Cambridge University Press.

Gramsci, A (1995), Further Selections from the Prison Notebooks, ed. and trans. D. Boothman. London, Lawrence \& Wishart.

Gramsci, A. (2007), Quaderni del Calcere: Quaderni di traduzioni (1929-1932), ed. G. Cospito \& G. Francioni, Rome, Istituto della Enciclopedia Italiana.

Gramsci, A. (2006), "Speech to the Italian Parliament", 16 $6^{\text {th }}$ May 1925, trans. by M. Carley, http://www.marxists.org/archive/gramsci/1925/05/speech.htm

Gramsci, A. (2013), Prison Notebooks (Volumes I-III), trans. by Joseph Buttigieg, Slp Edition, New York, Columbia University Press.

Lenin, V. (1982), Collected Works, Volume 31, Moscow https://www.marxists.org/archive/ lenin/works/cw/

Lyttelton, A. (1983), The Seizure of Power: Fascism in Italy 1919-1929, London, Weidenfeld \& Nicholas.

Machiavelli, N. (1981), The Prince, London, Penguin Classics.

Marx, K. (1999), Critique of Hegel's Philosophy of Right, Online version https://www.marxists.org/archive/marx/works/1859/critique-pol-economy/

Marx, K. (2008): Capital: Critique of Political Economy, "Book 1: The Process of Production of Capital, Online version http://www.marxistsfr.org/archive/marx/works/download/ Marx_Capital_Vol_1

Marx, K \& Engels, F. (1990).: Marx \& Engels Collected Works, Vol. 27, London, Lawrence \& Wishart.

Marx, K \& Engels, F. (2002), “Theses on Feuerbach”, Selected Works, Vol.1. http://www. marxists.org/archive/marx/works/1845/theses/theses.htm

Morton, A.D. (2007): Unravelling Gramsci: Hegemony and Passive Revolution in the Global Political Economy, London, Pluto Press.

Pozzolini, A. (1970): Antonio Gramsci: An Introduction to His Thought, London, Pluto Press.

Thomas, P.D. (2010): The Gramscian Moment: Philosophy, Hegemony and Marxism, Chicago, Haymarket Books. 